\title{
The Utilization of Gracilaria verrucosa as Fish Processing Wastewater Biofilter
}

\author{
Dhia Rahma Sari, Ratih Ida Adharini* \\ Department of Fisheries, Faculty of Agriculture, Universitas Gadjah Mada, Jl. Flora 1A Bulaksumur, \\ Yogyakarta, Indonesia
}

\begin{abstract}
Wastewater from the smoked-fish processing industry has been known to cause water pollution in Pengadulan Estuary, Jepara. This research aimed to assess the ability of Gracilaria verrucosa as biofilter for fish processing wastewater and investigate its growth rate. This study was conducted at the Center for Brackish Water Aquaculture (BBPBAP) Jepara from January to April 2019. This study used three different G. verucosa biomass in $60 \mathrm{~L}$ aquarium: 150 gram (A); 200 gram (B); and 250 gram (C) and control. The parameters observed in the study were seaweed biomass, nutrient uptake by seaweed, and water quality parameters: salinity, water temperature, $\mathrm{pH}$, dissolved oxygen, TSS, $\mathrm{BOD}_{5}$, ammonia $\left(\mathrm{NH}_{3}\right)$, nitrate $\left(\mathrm{NO}_{3}\right)$, and phosphate $\left(\mathrm{PO}_{4}\right)$. The results showed that G. verrucosa decreased ammonia, phosphate, and nitrate by $67.6 \%, 96 \%$, and $37.1 \%$, respectively. The result of RGR value has increased on the $10^{\text {th }}$ and $30^{\text {th }}$ day whereas on the $20^{\text {th }}$ day were declined. The highest RGR value obtained on the $10^{\text {th }}$ day on Treatment 1, which is $2.1 \%$ per day. It can be inferred that G. verrucosa is capable of increasing the water quality and the nutrient uptake in fish processing wastewater. Therefore, G. verrucosa held potential as both ecologically and economically sustainable biofilter.
\end{abstract}

\section{Introduction}

Fish processing is one of the developing industrial sectors, which indicated by the establishments of household-scale fish processing business. However, not all fish processing businesses perform wastewater processing. The liquid and solid wastes from fish processing activities were dumped directly into the surrounding waters every day. Although a running body of water is capable of self-purification, a continuous influx of wastewater could eventually pollute the estuary waters, causing an unpleasant stench in the surrounding waters.

Smoked fish wastewater, which contains organic materials, will decompose when dumped into the aquatic environment. The decomposition of organic materials produces simpler compounds in the form of inorganic materials. Excessive inorganic material accumulation can cause eutrophication, which could tip-off the balance of aquatic ecosystems [16;17], and making the waters hypoxic or anoxic [8].

Many efforts have been made to reduce the pollutant from wastewater, such as using biological filtration agents or biofilter. Aquatic plants as biofilters can be an easy and

\footnotetext{
*Corresponding author : ratih.adharini@ugm.ac.id
} 
economical solution for filtering wastewater [6, 11, 19]. Gracilaria, a red seaweed, has been known to be utilized as biofilter due to its capability to absorb inorganic nitrogen and phosphorous substances in wastewater [15, 19]. As a biofilter, Gracilaria is capable to remove $\mathrm{NH}_{4}-\mathrm{N} 59,5 \%, \mathrm{NO}_{3}-\mathrm{N} 49,6 \%$, and $\mathrm{PO}_{4}-\mathrm{P} 12,3 \%$ in 4 hours [8]. It is also can easily adapt to the surrounding environments because of its high tolerance to temperature, $\mathrm{pH}$, and salinity changes [3, 4]. Furthermore, G. verucossa is relatively easy to maintain and has a high economic value [5]. This research aimed to determine the ability of $G$. verrucosa as biofilter specifically to filter wastewater from the smoked-fish processing industry.

\section{Materials and Methods}

\subsection{Location and Time}

The research was conducted from January to April 2019 at the Center for Brackish Water Aquaculture (BBPBAP) Jepara. The fish wastewater collected from the smoked fish processing business which established around the Pengadulan Estuary of Jepara.

\subsection{Experimental Procedure}

This research was conducted using laboratory-scale experimental procedure using completely randomized design (CRD) which applied control and three different weight

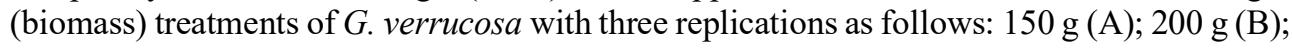
$250 \mathrm{~g}(\mathrm{C})$; and control treatment. Fish liquid waste was diluted by adding brackish water until the salinity reaches $20 \mathrm{ppt}$ for the purpose of adjusting the general environmental condition of $G$. verrucosa when it is grown in ponds, and the wastewater mixture was poured into a 60$\mathrm{L}$ aquarium. The acclimatization process was carried out for seven days, followed by an initial test to obtain weight treatment and accurate waste concentration. The experiment was conducted for 30 days. The observed parameters included water quality, Relative Growth Rate (RGR), and N and P content in seaweed tissue. Water quality observation included ammonia, nitrate, and phosphate.

The ammonia, nitrate, and phosphate test were conducted every 10 days. The ammonia measurement was conducted using salicylate method, nitrate content was measured using spectrophotometry method, and phosphate content was measured using phosphomolybdenum blue method where the concentration was measured using spectrophotometer [10]. RGR determination was conducted every 10 days. The $\mathrm{N}$ and $\mathrm{P}$ content measurement in G. verrucosa tissue was conducted before and after the treatment. N Measurement followed AOAC [1] while P measurement used SNI [2].

\subsection{Determining the Relative Growth Rate (RGR)}

According to Cirik et al. [4], Relative Growth Rate (RGR) can be calculated using the following formulation:

$$
R G R=\frac{[L n(W t / W o)]}{t 2-t 1} \times 100
$$

$\mathrm{RGR}=$ relative growth rate $(\%)$

$\mathrm{Wt}=$ average weight of seaweed on the t-day $(\mathrm{g})$

Wo $=$ average weight of seaweed on the $0^{\text {th }}$ day $(\mathrm{g})$

$\mathrm{t}_{2} \quad=$ weighing time on the $\mathrm{t}_{2}$ (day)

$\mathrm{t}=$ weighing time on the $\mathrm{t}_{1}$ (day) 


\subsection{Statistical Analysis}

The descriptive analysis was performed to find out the inorganic material contained in each treatment. The statistical analysis of nitrate, ammonia, phosphate, and RGR was done using homogeneity and normality test, followed by one-way ANOVA test to find out whether there is a distinct difference or not [8]. If a distinct difference obtained, then a further Tukey test was conducted. The $\mathrm{N}$ and $\mathrm{P}$ content in the tissue is analyzed using t-partner test to find out whether there is a distinct difference before the treatment or not. A significance level of $95 \%$ $(\alpha=0.05)$ was set for all the tests [7]. Statistical analyses were performed using SPSS software version 20.0 .

\section{Results}

\subsection{Nutrient Removal}

Concentration fluctuation of ammonia, nitrate, Phosphate occurred because of the ammonification and nitrification process. However, ammonia, nitrate, and phosphate decreased significantly in the last third period. The Ammonia decreased on the $10^{\text {th }}$ day, nitrate on the $20^{\text {th }}$ day, and phosphate on the $0^{\text {th }}$ day. The use of G.verrucosa can improve the water quality of wastewater faster than control.

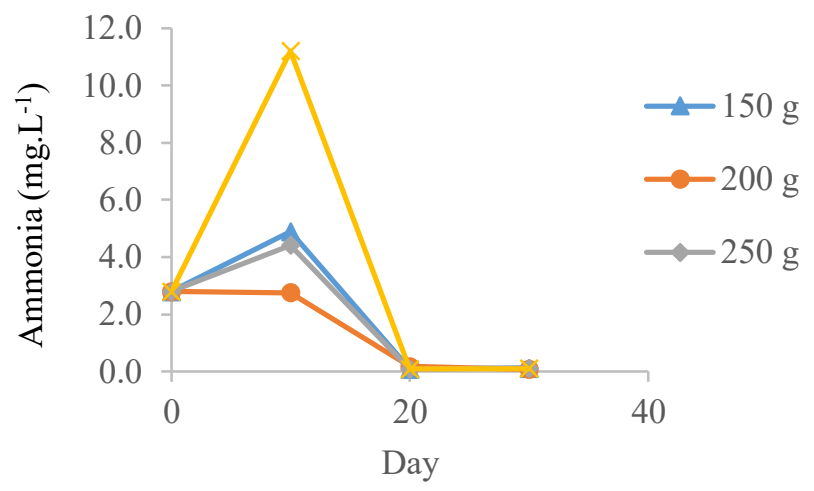

Fig. 1. The ammonia content of fish processing wastewater during treatment

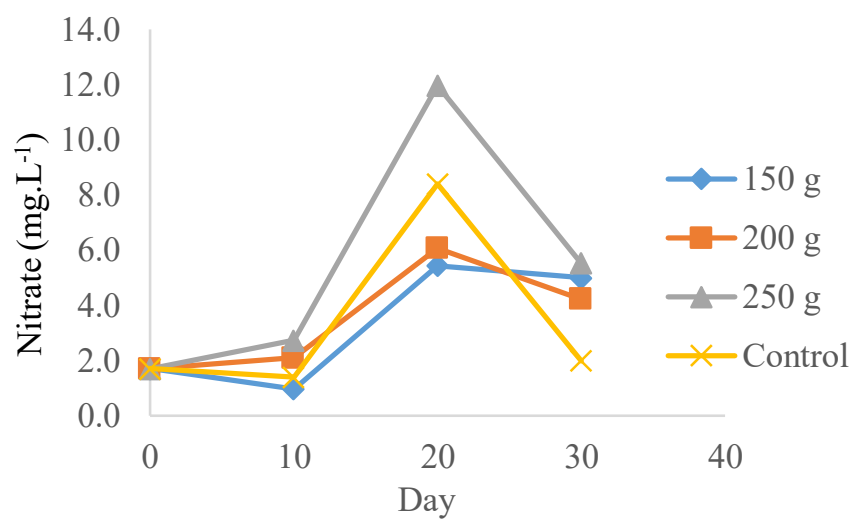

Fig. 2. The nitrate content of fish processing wastewater during treatment 


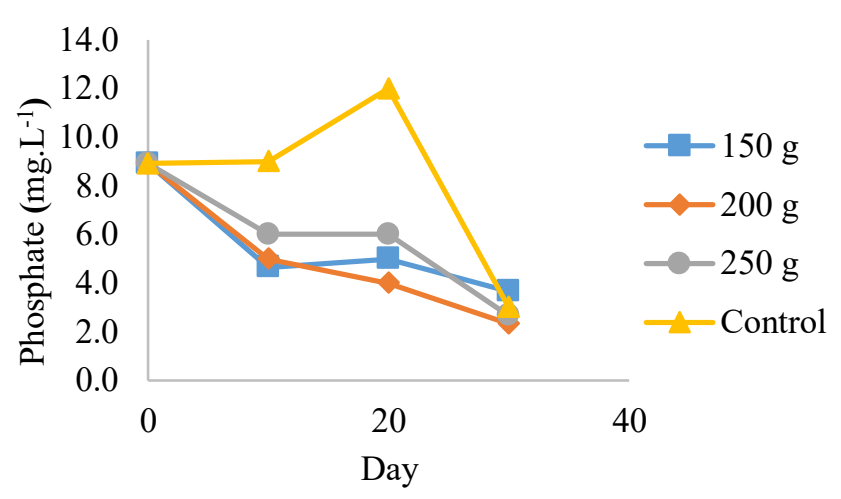

Fig. 3. Phosphate content of fish processing wastewater during treatment

\subsection{RGR (Relative Growth Rate)}

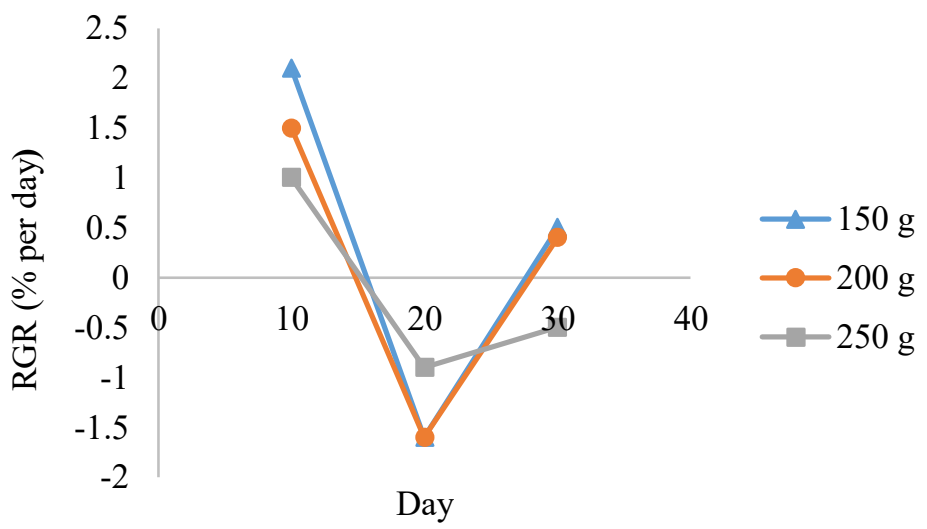

Fig. 4. Relative Growth Rate of G. verrucosa during treatment

The increase of seaweed biomass occurred on the $10^{\text {th }}$ day. The RGR for $150 \mathrm{~g}$ treatment was $2.1 \%$ per day, and for $250 \mathrm{~g}$ was $1.5 \%$ per day, while the treatment of $250 \mathrm{~g}$ was $1 \%$ per day. On the $20^{\text {th }}$ day, seaweed biomass had a negative growth rate compared to the $10^{\text {th }}$ day. Biomass growth at the end of the period on the treatment of $150 \mathrm{~g}$ and $200 \mathrm{~g}$ is $0.5 \%$ per day and $0.4 \%$ per day subsequently. While the treatment of $250 \mathrm{~g}$ experienced biomass reduction with $-0.5 \%$ per day. The biomass reduction is caused by the $\mathrm{N}$ and $\mathrm{P}$ content in the wastewater that will be absorbed also experienced lower concentration. According to Páez-Osuna et al. [10], alga biomass is influenced by water nutrient content.

\subsection{Nutrient uptake of G. verrucosa}

Initial $\mathrm{N}$ content on $G$. verrucosa tissue was $0.16 \%$ of the dry weight. The final $\mathrm{N}$ content decreased with the highest decrease in the treatment of $150 \mathrm{~g}$, which was $0.1 \%$, treatment $250 \mathrm{~g}$ was $0.12 \%$, and $200 \mathrm{~g}$ was $0.14 \%$ (Table 1 ). The P content of G. verrucosa tissue between the beginning and the end of the experiment showed improvement. The highest increase was on the treatment of $250 \mathrm{~g}$, which was $0.89 \%$ (Table 2 ). 
Table 1. Nitrogen content in G. verrucosa tissue during treatment

\begin{tabular}{lll}
\hline \multirow{2}{*}{ Treatments } & \multicolumn{2}{c}{ Total N (\%) } \\
\cline { 2 - 3 } & Day 0 & Day 30 \\
\hline A (150 g) & 0.16 & 0.1 \\
B (200 g) & 0.16 & 0.14 \\
C (250 g) & 0.16 & 0.12 \\
\hline Average & 0.16 & 0.12 \\
\hline
\end{tabular}

*) The values in the column followed by the same letter indicate no significant difference at the $95 \%$ significance level

Table 2. Phosphorous content in G. verrucosa tissue during treatment

\begin{tabular}{llc}
\hline \multirow{2}{*}{ Treatments } & \multicolumn{2}{c}{ Total P (\%) } \\
\cline { 2 - 3 } & Day 0 & Day 30 \\
\hline A (150 g) & 0.31 & 0.79 \\
B (200 g) & 0.31 & 0.75 \\
C (250 g) & 0.31 & 0.89 \\
\hline Average & $0.31^{\mathrm{b}}$ & $0.81^{\mathrm{a}}$ \\
\hline
\end{tabular}

*) The values in the column followed by the same letter indicate no significant difference at the $95 \%$ significance level

\section{Discussion}

The ammonia content from the wastewater mixture was decreased from $1.8 \mathrm{mg} . \mathrm{L}^{-1}$ to 0.1 mg. $\mathrm{L}^{-1}$. The result showed an improvement of wastewater quality. The ammonia on the $10^{\text {th }}$ day increased because organic nitrogen had been converted to form ammonia. This process is known as the ammonification process.

There was a significant difference between the treatment of $200 \mathrm{~g}$ and $250 \mathrm{~g}$ of $G$. verrucosa on the $20^{\text {th }}$ day. The treatment of $250 \mathrm{~g}$ has lower ammonia content because able to absorb ammonia more effectively. The increased ammonia content on the $10^{\text {th }}$ day of treatment can be reduced by G. verrucosa. Furthermore, it can reduce the ammonia content in water up to $97.5 \%$ for 30 days. According to Schuenhoff et al. [14], the implementation of biofilter by seaweed can decrease the available ammonia to $70 \%$ every day.

The concentration of ammonia is higher than nitrate in polluted water. The condition of the wastewater mixture at the beginning of the experiment was similar to polluted water, the ammonia content was higher than nitrate. However, at the end of the research period, the ammonia was decreased, and nitrate was increased. High concentration of nitrate in either freshwater or estuary waters can cause fish mortality. According to Rudde \& Lange [13], more than $30 \mathrm{ppm}$ of nitrate can inhibit growth, disrupting the immune system, and cause stress in some aquatic organisms. In seaweed, nitrate stimulates thallus formation [12]. The 
nitrogen removal process in the water occurred from the oxidation of ammonia into nitrite, forming nitrate (nitrification process) on aerobic conditions [18]. However, nitrate concentration at the end of the research period was not significantly different from the initial period. It may be caused by the still-occurring nitrification process during the research period of 30 days, which resulted in an increase in nitrate concentration. The increase of nitrate content is relevant to the research performed by Marinho-Soriano et al. [7] in which the nitrate content in the water increased for four weeks during G. birdiae treatment which occurred on the first and third week. However, at the end of the research, nitrate concentration decreased by $37.1 \%$ after the $20^{\text {th }}$ day.

Wastewater treated with $G$. verrucosa showed an effective decrease in phosphate content. This indicates that phosphate is absorbed by $G$. verrucosa, hence dissolved phosphate concentration decreased in the wastewater. The biomass of $G$. verrucosa was increased on the $10^{\text {th }}$ day. Seaweed is capable to accumulate phosphate in their cells if the phosphate concentration in water is high. Phosphate is required by seaweed as its supporting factor in the photosynthesis process [12].

The phosphate concentration was higher on the $20^{\text {th }}$ day. The result showed lower RGR value on the $20^{\text {th }}$ day, which could indicate that the G. verrucosa condition was too weak to absorb phosphate optimally. However, G. verrucosa can still significantly reduce phosphate concentration compared to the control treatment. In the control treatment, the phosphate content was increased to $12 \mathrm{mg} . \mathrm{L}^{-1}$, treatment $\mathrm{A}(150 \mathrm{~g})$ increased to $5 \mathrm{mg} . \mathrm{L}^{-1}$, the concentration in treatment $C(250 \mathrm{~g})$ was relatively constant, while in treatment $\mathrm{C}(200 \mathrm{~g})$ the concentration decreased to $4 \mathrm{mg} . \mathrm{L}^{-1}$. Phosphate concentrations were decreased in all treatments by the end of the research. The reduction of phosphate concentration in the water was caused due to absorption by G.verrucosa and sedimentation. More sediments were formed in the control treatment compared to the seaweed treatments. In this study, $G$. verrucosa can reduce phosphate by $64.8 \%$ for 30 days.

The highest relative growth rate of $G$. verrucosa found in this study was $2.1 \%$ per day. In a similar study conducted by Cirik et al [4], the RGR of $G$. verrucosa which was treated for five months reached $2.46 \%$ per day. There was no significant difference among treatments that influence the RGR. However, there was a significant difference in seaweed RGR between the $10^{\text {th }}, 20^{\text {th }}$, and $30^{\text {th }}$ day.

Phosphorous (P) content in the tissue of $G$. verrucosa showed a significant difference $(\mathrm{p}<0.05)$. G. verrucosa can absorb the phosphate concentration in wastewater. Phosphorous (P) content on seaweed tissue in the end research period reached $0.81 \%$ while $\mathrm{N}$ obtained $0.12 \%$. P content on the research is higher than the average content obtained by MarinhoSoriano et al. result [8], which obtained $0.20 \%$. N content on $G$. verrucosa tissue was obtained in the last period of research $(0.12 \%)$, while the average $\mathrm{N}$ content obtained in Marinho-Soriano et al. [8] was $0.26 \%$.

Based on the results of this study, we concluded that G. verrucosa is capable as biofilter for treating smoked fish processing wastewater. G. verrucosa absorbed $\mathrm{P}$ higher than $\mathrm{N}$ content in their tissue. G. verrucosa can reduce inorganic material in wastewater effectively. It can also decrease ammonia, phosphate, and nitrate content in water by $67.6 \%, 96 \%$, and $37.1 \%$, respectively, with maximum relative growth rate of $2.1 \%$ per day.

\section{References}

1. AOAC International. Official Methods of Analysis of AOAC International. AOAC International, Arlington. (2016)

2. Badan Standarisasi Nasional. SNI 2803-2012 Pupuk NPK Padat. Badan Standarisasi Nasional, Jakarta. (2012) (In Indonesian) 
3. H.G. Choi, Y.S. Kim, J.H. Kim, S.J. Lee, E.J. Park, J. Ryu and K.W. Nam. Effects of Temperature and Salinity on the Growth of Gracilaria verrucosa and G. chorda, with the Potential for Mariculture in Korea. Journal of Applied Phycology. (18): 269-277. (2006.)

4. S. Cirik, Z. Cetin, I. Ak, S. Cirik, and T. Goksan. Greenhouse Cultivation of Gracilaria verrucosa (Hudson) Papenfus and Determination of Chemical Composition. Turkish Journal of Fisheries and Aquatic Sciences. (10): 559-564. (2010)

5. W. Komarawidjaja. Peluang Pemanfaatan Rumput Laut sebagai Agen Biofiltrasi pada Ekosistem Perairan Payau yang Tercemar. J. Tek. Ling. 4(3): 155-159. (2003) (In Indonesian)

6. Q. Liu, M. Li, R. Chen, Z. Li, G. Qian, T. An, J. Fu, and G. Sheng. Biofiltration treatment of odors from municipal solid waste treatment plants. Waste Management. 29(7): 20512058. (2009)

7. E. Marinho-Soriano, S. O. Nunes, M. A. A. Carneiro dan D.C. Pereira. Nutrients' Removal from Aquaculture Wastewater Using the Macroalgae Gracilaria birdiae. Biomass and Bioenergy. (33):327-331. (2009)

8. E. Marinho-Soriano, R.A. Panucci, M.A.A. Carneiro dan D.C. Pereira. Evaluation of Gracilaria caudate J. Agardh for Bioremediation of Nutrients from Shrimp Farming Wastewater. Bioresource Technology. (100): 6192-6198. (2009)

9. A. Mentari, N. Probosunu, R. I. Adharini. Utilization of Azolla sp. Decrease COD (Chemical Oxygen Demand) Content in Laundry Waste Water. Jurnal Perikanan Universitas Gadjah Mada. 18(2): 67-72. (2016)

10. F. Páez-Osuna, A. Piñón-Gimate, M. J. Ochoa-Izaguirre, A. C. Ruiz-Fernández, G. Ramírez-Reséndiz, and R. Alonso-Rodríguez. Dominance pattern in macroalgal and phytoplankton biomass under different nutrient loads in subtropical coastal lagoons of the SE Gulf of California. Marine Pollution Bulletin. 77: 274-281. (2013)

11. E. G. I. Payne, T. Pham, P. L. M. Cook, T. D. Fletcher, B. E. Hatt, A. Deletic. Biofilter design for effective nitrogen removal from stormwater-influence of plant species, inflow hydrology and use of a saturated zone. Water Science \& Technology. 69(6): 1312-1319. (2014)

12. P.R. Pong-Masak and N.H. Sarira. Penentuan Jarak Tanam Optimal Antar Rumpun Bibit pada Metode Vertikultur Rumput Laut. Jurnal Perikanan Universitas Gadjah Mada. 20(1): 23-30. (2018) (In Indonesian)

13. H. Rudde and H. Lange. Method of Determining a Concentration of Nitrate. Patent Application Publication United States. (2014) http://www.freepatentsonline.com/20140011283.pdf >. accessed 24 Juni 2019.

14. A. Scuenhoff, M. Shpigel, I. Lupatsch, A. Ashkenazi, F. E. Msuya dan A. Neori. A SemiRecirculating, Integrated System for The Culture of Fish and Seaweed. Aquaculture. (221): 167-181 (2003)

15. T. K. Shah, I. Nazir, P. Arya, and T. Pandey. Integrated multi trophic aquaculture (IMTA): An innovation technology for fish farming in India. International Journal of Fauna and Biological Studies. 4(1): 12-14. (2017)

16. R. Wartenberg, L. Feng, J. J. Wu, Y. L. Mak, L.L. Chan, T. C. Telfer, P. K. S. Lam. Ecosystem Health and Sustainability. 3(6): 1-20. (2017)

17. Z. Wei, J. You, H. Wu, F. Yang, L. Long, Q. Liu, Y. Huo, and P, He. Bioremediation using Gracilaria lemaneiformis to manage the nitrogen and phosphorus balance in an integrated multi-trophic aquaculture system in Yantian Bay, China. Marine Pollution Bulletin. 121: 313-319. (2017) 
18. C. C. Yun and G. Redzwan. Biological Treatment of Fish Processing Saline Wastewater for Reuse as Liquid Fertilizer. Sustainability 9(7): 1-26. (2017)

19. Y. Zhou, H. Yang, H. Hu, Y. Liu, Y. Mao, H. Zhou, X. Xu, and F. Zhang. Bioremediation Potential of the Macroalga Gracilaria lemaneiformis (Rhodophyta) Integrated into Fed Fish Culture in Coastal Waters of North China. Aquculture (252): 264-276. (2006) 